\title{
Coastal cliff temperatures related to the potential for cryogenic weathering processes, western Spitsbergen, Svalbard
}

\author{
RUNE STRAND ØDEGÅRD and JOHAN LUDVIG SOLLID
}

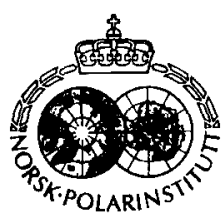

\begin{abstract}
Ødegård, R. S. \& Sollid, J. L. 1993: Coastal cliff temperatures related to the potential for cryogenic weathering processes, western Spitsbergen, Svalbard. Polar Research 12(1), 95-106.

The main purpose of this research was to measure the near surface ground temperatures and describe the main characteristics of the thermal regime of a sheltered arctic coastal cliff. Measurements were made near $\mathrm{Ny}$-Ålesund, western Spitsbergen, Svalbard $\left(79^{\circ} \mathrm{N}, 12^{\circ} \mathrm{E}\right)$, in a transect across sediments on top of a coastal cliff, in a $8 \mathrm{~m}$ high coastal cliff and across the beach below the cliff. Temperatures were logged hourly from August 1987 to August 1988. A local snow cover of $1-4 \mathrm{~m}$ on the beach had a strong influence on surface heat exchange, and hence the dynamics of the ground thermal regime. Late winter temperatures in the cliff and backshore sediments were stable and ranged from $-5^{\circ} \mathrm{C}$ to $-9^{\circ} \mathrm{C}$. At the first snow melt events in spring there was a large heat flux into the ground due to the release of latent heat from refreezing of meltwater. The interpretation of the temperature records leads to a discussion on some aspects of cryogenic weathering. The snow-melt period in spring and summer may be a period of rock fracturing, based on the model of segregation ice growth at subzero temperatures. Steep temperature gradients and available meltwater at the surface favor water migration in the heavily fractured dolomitic limestone even at the low hydraulic conductivities expected at below zero temperatures.
\end{abstract}

R. S. Ødegdrd and J. L. Sollid, Department of Physical Geography, University of Oslo, P.O. Box 1042 Blindern, N-0316 Oslo, Norway

\section{Introduction}

Svalbard comprises a group of islands situated between latitudes $74^{\circ} \mathrm{N}$ and $81^{\circ} \mathrm{N}$ and longitudes $10^{\circ} \mathrm{E}$ and $35^{\circ} \mathrm{E}$. The western coast of the main island Spitsbergen is exposed to relatively warm Atlantic Water.

Maps of the coastal geomorphology of Svalbard, excluding Nordaustlandet, show welldeveloped coastal cliffs along $25 \%$ of the coastline (Ødegård et al. 1987; Høgvard \& Sollid 1988a, b, $1989,1990,1991,1992)$. Low vertical coastal cliffs with erosion in bedrock are most frequent in fjord areas in northwestern Spitsbergen, including Isfjorden, and in the inner parts of Storfjorden on the eastern coast. The fjords generally have a low energy coast as the ice-foot and sea ice protect the cliffs from wave energy during most of the year. Coastlines with long fetch and less sea ice along the headlands normally have pocket beaches with low bedrock outcrops or continuous beaches. Submerged strandflat areas along most of the outer western coast of Spitsbergen reduce the amount of wave energy reaching the shore.
Arctic coastal rock cliffs are subjected to diverse subaerial and marine weathering processes. Frost weathering was already proposed by Högbom (1914) and Nansen (1922) to be an important process in the formation of the coastal cliffs characteristic of Spitsbergen fjords. Nansen also suggested that the strandflat forms by the interaction of frost weathering and marine processes at coastal rock cliffs, with frost weathering as the main fracturing agent and marine processes responsible for the removal and transport of material. The strandflat belongs to high latitude coasts, and its origin has been discussed by Reusch (1894), Ahlmann (1919), Nansen (1922) and several others.

The fractured appearance of the sheltered coastal rock walls and the amount of angular rock fragments that accumulate on snow and ice-foot during spring show that subaerial mechanical weathering is active (O. Liestøl pers. commun.). In sheltered areas snow and ice usually persist until late autumn just above high tide, indicating that limited amounts of marine energy reach the cliffs in summer. Marine erosion at sheltered sites 
is probably restricted to storms recurring at intervals of several years. During the entire research period of one year the sediments close to the investigated cliff were not disturbed by waves.

No earlier quantitative measurements of coastal cliff retreat in Svalbard are known to the authors. In the research area the abrasion platform is $10-15 \mathrm{~m}$ wide. An average Holocene retreat rate is difficult to calculate due to limited knowledge of the sea level after the Tapes transgression (Forman et al. 1987) and to the possibility of a pre-Holocene cliff being reoccupied by the present sea level. No measurements of present weathering rates were attempted.

The main purpose of this research was to measure the near surface ground temperatures and describe the main characteristics of the thermal regime of a sheltered Arctic coastal cliff. The influence of the macroclimate and local factors such as snow cover and available water are discussed. Based on the temperature records and a rough evaluation of moisture conditions, some aspects of the potential for cryogenic weathering processes in the rock cliffs of this type are discussed.

Recent advances in cryogenic weathering research provide guidance for discussing cryogenic weathering based on temperature records. Reviews of cryogenic weathering are given by McGreevy (1981) and Lautridou (1988). Laboratory research has shown that oscillations around $0^{\circ} \mathrm{C}$ are less significant than formerly assumed regarding fragmentation of most rocks. Laboratory experiments show critical temperatures for rock fracturing from $-3^{\circ} \mathrm{C}$ to below $-10^{\circ} \mathrm{C}$ (Mellor 1973; McGreevy 1982; Lautridou \& Ozouf 1982; Letavernier \& Ozouf 1987). Using a theoretical model of segregation ice growth at subzero temperatures, Hallet (1983) showed that the most rapid expansion of preexisting microcracks in an open system in rocks is expected in the interval from $-5^{\circ} \mathrm{C}$ to $-15^{\circ} \mathrm{C}$, depending on available water, the rock properties and the temperature gradient on the warmer side of the crack. This model has recently been supported by an experimental study using a porous sandstone (Hallet et al. 1991).

Quantitative analysis of the processes that operate in the Arctic coastal zone is extremely difficult. No attempt is made to provide a complete evaluation of the site specific processes. A more comprehensive discussion of the subaerial process would have to include data on the fracture-mech- anical properties of different rocks and measurements of moisture conditions. Such data are not available.

\section{Study area}

\section{Location and setting}

Temperatures were measured at a north-facing dolomitic limestone cliff located on the south side of inner Kongsfjorden on the western coast of Spitsbergen (Fig. 1). The site is moderately exposed to wave energy (Figs. 2 and 3). Large parts of the coastal cliff have subsequently been removed in the construction of a new quay. The beach was $14 \mathrm{~m}$ wide and backed by an $8 \mathrm{~m}$ high coastal rock cliff.

The study site is located $450 \mathrm{~m}$ from the meteorological station in $\mathrm{Ny}$-Ålesund. The mean annual air temperature (MAAT) was $-6.0^{\circ} \mathrm{C}$ in the period 1971-1988. The mean annual ground temperature (MAGT) is believed to be about $-5^{\circ} \mathrm{C}$, based on measurements in a former coal mine (Orvin 1944). The mean air temperature from September 1987 through August 1988 was $-7.6^{\circ} \mathrm{C}$, reflecting an unusually cold winter; the September to May average air temperature was the third coldest in 20 years. Especially low air temperatures in the period of a thin snow cover in December and January imply lower than average ground temperatures in the research period (Fig. 4).

\section{Snow, ice-foot and sea-ice conditions}

The snow accumulation in the 1987-1988 season was average provided that winter accumulation on the glacier Austre Brøggerbreen $3 \mathrm{~km}$ from $\mathrm{Ny}-\AA ̊$ lesund is assumed to be representative of the coastal zone. There is a 20-year record of mass balance from Austre Brøggerbreen (Liestøl 1988; Hagen \& Liestøl 1990). No snow depth measurements are available from the meteorological station.

Snow began to accumulate at the foot of the cliff in September, and by the end of October the local snow depth was $2.0 \mathrm{~m}$. Snow accumulation reached the top of the cliff (which was usually free of snow until this time) in early December. In mid-December the snow depth at the top of the cliff was $0.25 \mathrm{~m}$. From the end of February the cliff-top snow cover stabilized at $0.55-0.65 \mathrm{~m}$ 


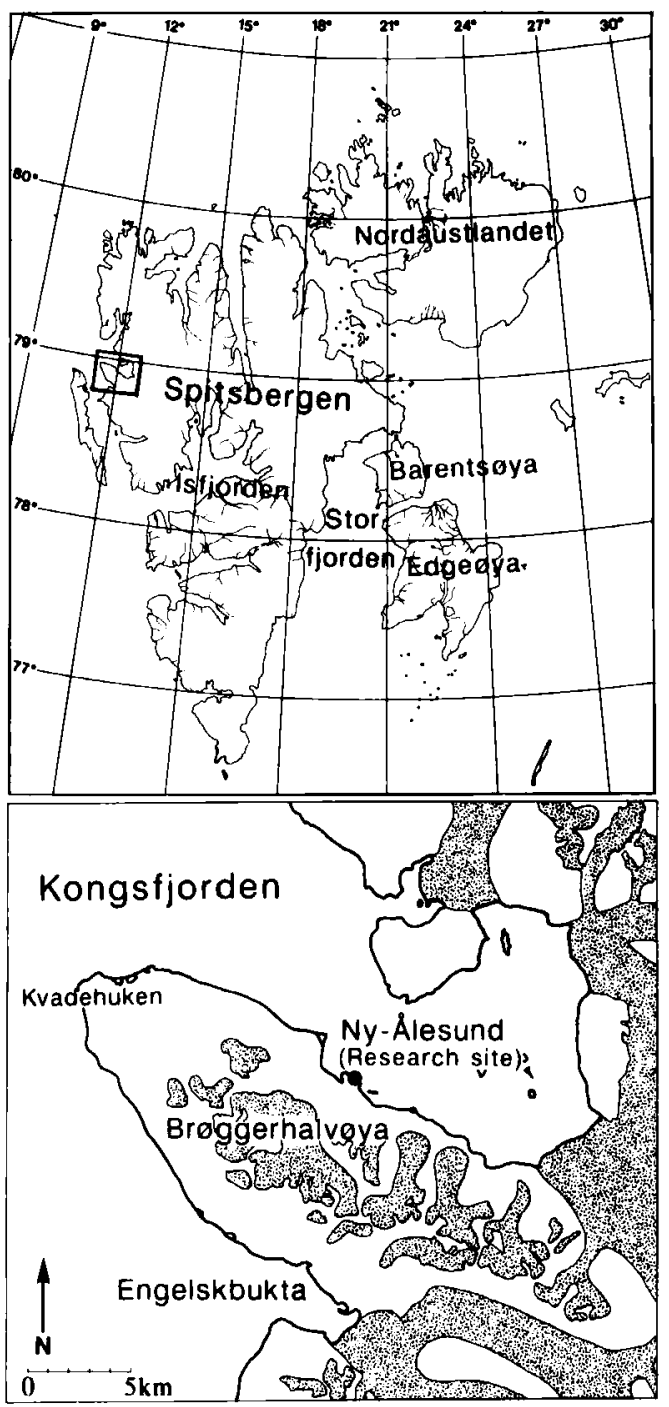

Fig. 1. The research site near $\mathrm{Ny}$-Ålesund on the western coast of Spitsbergen, Svalbard. Shaded areas are glaciers. until 7 May-10 May when the spring melt began (Fig. 4).

In 1987 snow and ice had not melted by the end of August (Fig. 3). This year had the second coldest June, July and August of the previous 20 years. After a summer of average temperatures in 1988, snow and ice remained until the middle of August.

The western coast of Spitsbergen has semidiurnal tides. At the research site the average maximum range is $1.8 \mathrm{~m}$. The maximum tidal range during 15 years of observations in Ny-Ålesund is $2.3 \mathrm{~m}$. The average high tide is $0.6 \mathrm{~m}$ above mean sea level (T. Eiken pers. commun.). In 1987 a tidal ice-foot was formed in sheltered areas of Kongsfjorden as an ice terrace at the level of maximum high tide. The ice-foot protected the backshore from nearly all wave energy during the autumn. At the research site the height of the icefoot varied from $0.61 \mathrm{~m}$ to $0.77 \mathrm{~m}$ above mean sea level.

According to Wiseman \& Coleman (1978), there is considerable spatial and temporal variability in ice conditions and ice-foot morphology. The inner part of Kongsfjorden is usually frozen, at least during some of the winter. There were no storms at the research site during the period without ice-foot and sea ice in autumn 1987 and summer 1988.

\section{Methods and results}

Thermistors were used for the ground temperature measurements. The absolute accuracy was estimated to be $\pm 0.1^{\circ} \mathrm{C}$ close to $0^{\circ} \mathrm{C}$, increasing to $\pm 0.2^{\circ} \mathrm{C}$ at the ends of the interval $\pm 20^{\circ} \mathrm{C}$. The resolution was $0.01^{\circ} \mathrm{C}$ for the whole range. Ten thermistors were places in a transect across
Fig. 2. Transect across the investigated site. A nearby coastal cliff at the location of thermistor 7 is included. Shaded areas on land are marine beach material. In the intertidal zone the ice-foot and sea ice are shaded. Numbers 1 to 10 show location of thermistors.

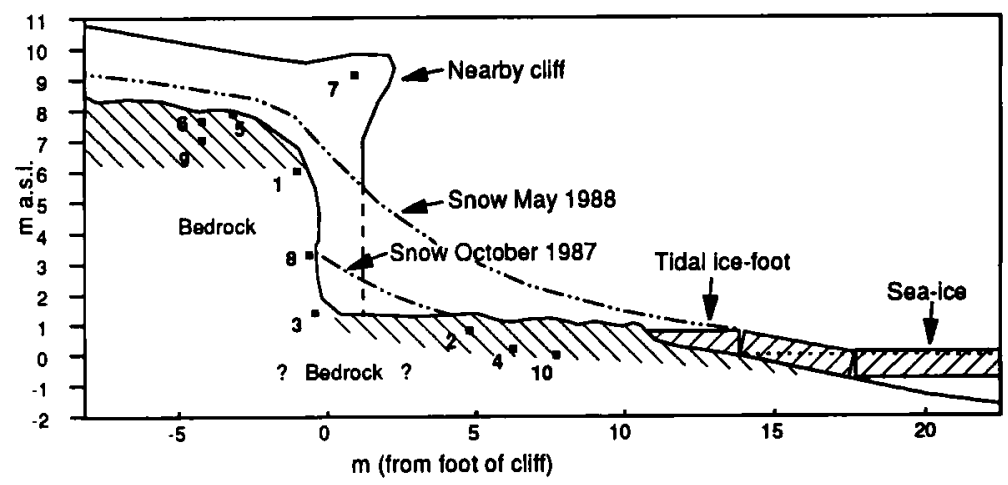



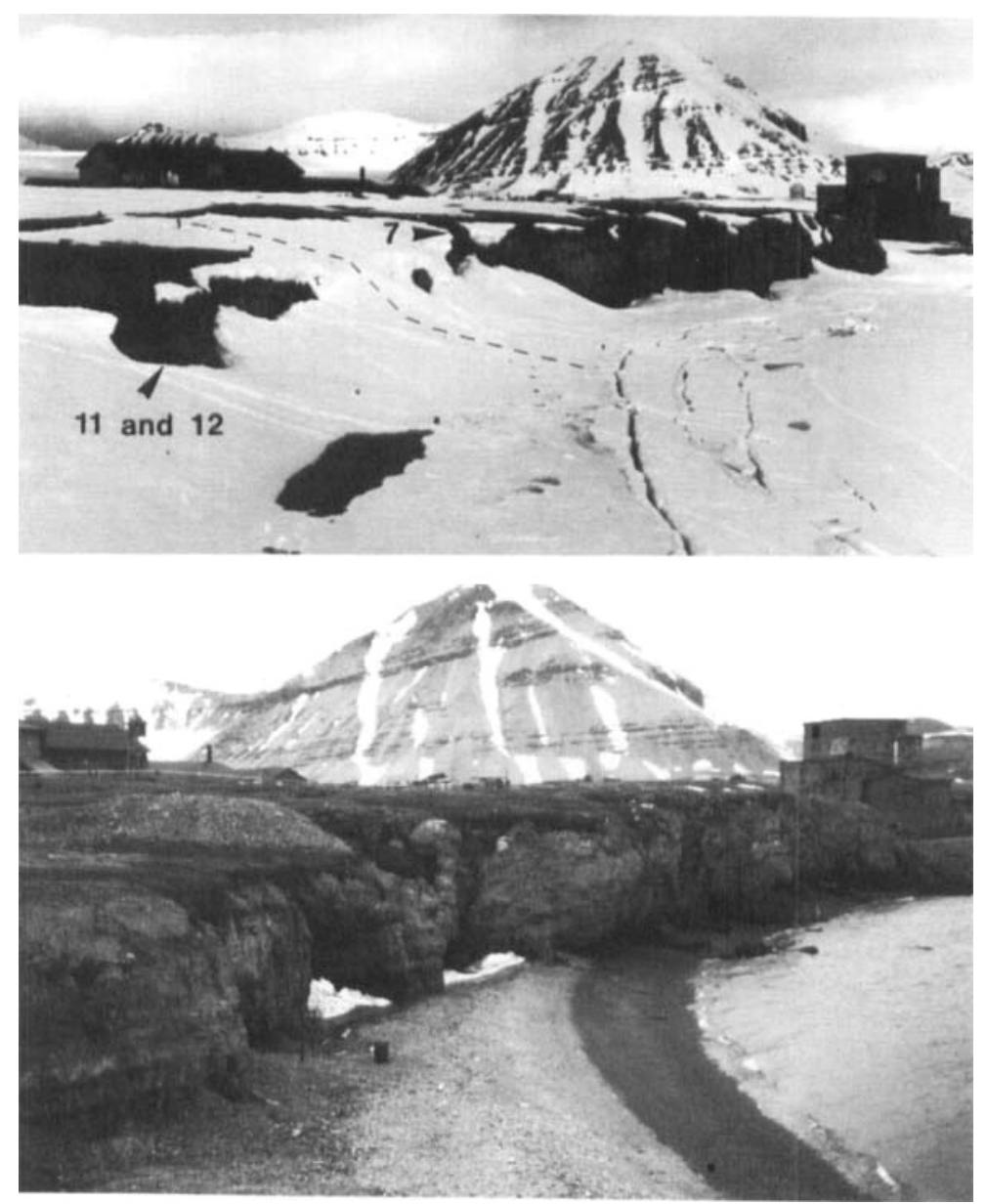

Fig. 3. View to the south-west of the study site. The shore and the cliff face north and are moderately exposed to wave energy. The upper photo is from 24 May 1988. The locations of thermistors 7,11 and 12 are shown. The dashed line indicates the main section. The lower photo is from late August 1987 and shows snow and ice at the foot of the cliff.

backshore sediments and across a rock cliff situated on the south coast of Kongsfjorden, just west of the first quay in Ny-Ålesund (Figs. 2 and 3). Ground temperatures were measured at hourly intervals from 26 August 1987 to 26 August 1988 at depths ranging from $0.05-1.20 \mathrm{~m}$. Two additional thermistors recorded temperatures in the outer shell of the cliff face during the summer only (20 May-26 August, 1988).

The mean annual values of ground temperature varied from $-6.3^{\circ} \mathrm{C}$ (thermistor 7 ) on an exposed part of the cliff with little snow cover to $-2.9^{\circ} \mathrm{C}$ (thermistor 10) in shore sediments at mean sea level (Fig. 2 and Table 1). The average value at the foot of the cliff was $-3.9^{\circ} \mathrm{C}$. The lowest mean ground temperature of $-6.3^{\circ} \mathrm{C}$ is $1.3^{\circ} \mathrm{C}$ warmer than the mean air temperature of the same period.

Thermistors 5 and 6 were placed $3.75 \mathrm{~m}$ apart at $0.05 \mathrm{~m}$ and $0.35 \mathrm{~m}$ depth in the flat area on top of the cliff. The maximum snow depths were $0.75 \mathrm{~m}$ and $0.70 \mathrm{~m}$ respectively. The mean annual ground temperatures of $-5.4^{\circ} \mathrm{C}$ and $-5.0^{\circ} \mathrm{C}$ were $2.2^{\circ} \mathrm{C}$ and $2.6^{\circ} \mathrm{C}$ warmer than the mean air temperatures of the period. These mean values are probably representative of flat areas with vegetation near the coast. These differences between mean ground and mean air temperature deviate little from those at an alpine permafrost site in southern Norway, estimated to range from $2.2^{\circ} \mathrm{C}$ to $2.4^{\circ} \mathrm{C}$ in a flat area with a maximum snow depth of $0.50 \mathrm{~m}$ (Ødegård et al. 1992).

\section{Autumn and early winter}

At thermistor 8 there was only a slight delay in cooling close to $0^{\circ} \mathrm{C}$, indicating a dry freezing in the rock wall. This was in contrast with thermistor 3 at the foot of the cliff and thermistors 6 and 9 
Fig. 4. A. Snow accumulation on top of the cliff. B. Mean monthly air temperatures in the rescarch period, plotted versus mean monthly temperatures in the period 1966 to 1988 . Dashed lines are \pm one standard deviation of mean monthly temperatures.

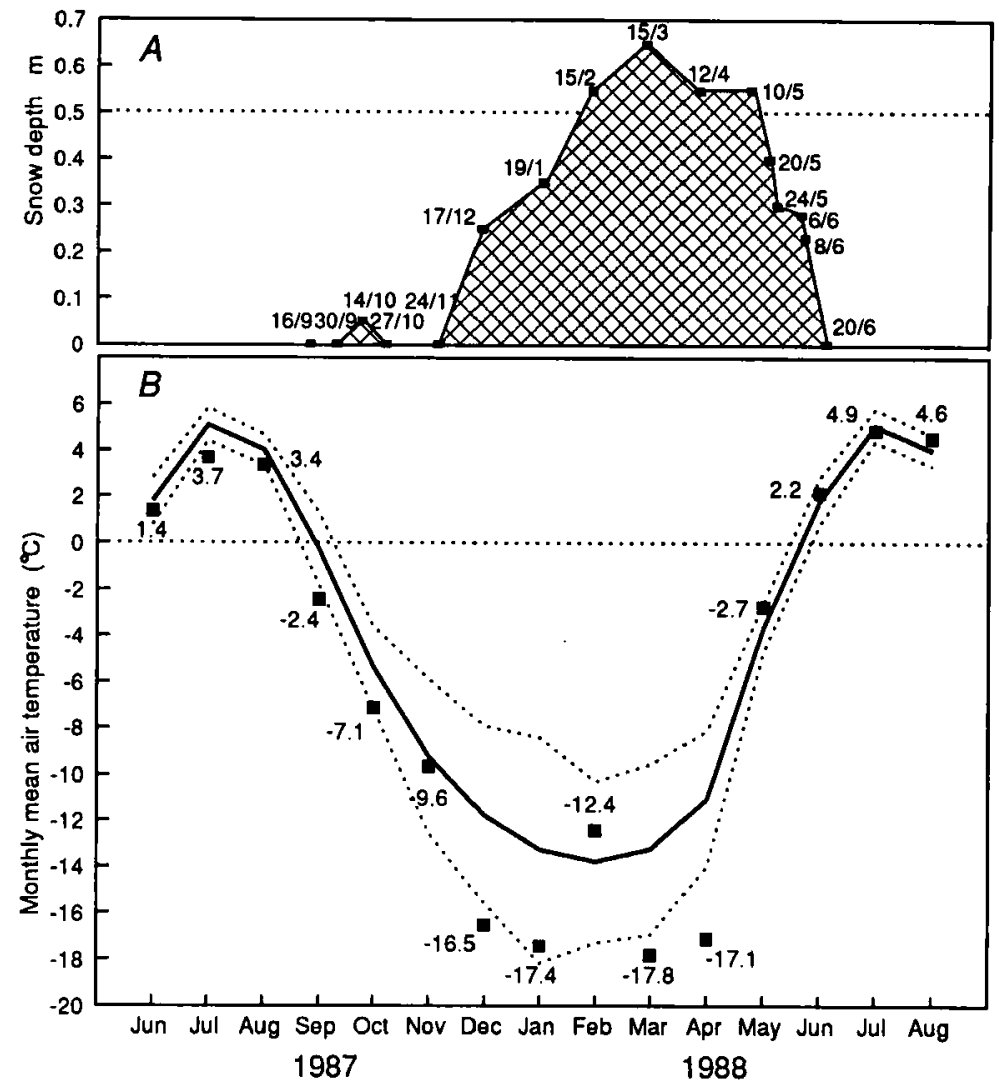

Table 1. Avcrage and extreme temperatures.

\begin{tabular}{|c|c|c|c|c|c|c|}
\hline Number & $\begin{array}{l}\text { Depth } \\
\text { m }\end{array}$ & $\begin{array}{l}\text { Average } \\
\text { values } \\
{ }^{\circ} \mathrm{C}\end{array}$ & $\begin{array}{l}\text { Maximum } \\
{ }^{\circ} \mathrm{C}\end{array}$ & $\begin{array}{l}\text { Minimum } \\
{ }^{\circ} \mathrm{C}\end{array}$ & $\begin{array}{l}\text { Maximum } \\
\text { rise } \\
{ }^{\circ} \mathrm{C} / \mathrm{h}\end{array}$ & $\begin{array}{l}\text { Maximum } \\
\text { drop } \\
{ }^{\circ} \mathrm{C} / \mathrm{h}\end{array}$ \\
\hline 1 & 0.36 & -5.5 & 17.8 & -18.1 & 2.23 & 1.12 \\
\hline 2 & 0.40 & -4.0 & 3.0 & -11.8 & 2.92 & 0.63 \\
\hline 3 & 0.60 & -3.9 & 1.1 & -6.3 & 0.21 & 0.10 \\
\hline $4^{*}$ & 0.90 & -4.0 & 0.0 & -7.2 & 0.28 & 0.45 \\
\hline 5 & 0.05 & -5.4 & 13.0 & -19.2 & 1.87 & 1.71 \\
\hline 6 & 0.35 & -5.0 & 4.3 & -11.7 & 0.24 & 0.14 \\
\hline 7 & 0.55 & -6.3 & 13.5 & -20.6 & 0.36 & 0.43 \\
\hline 8 & 0.25 & -4.4 & 10.6 & -10.6 & 0.96 & 0.69 \\
\hline $9^{*}$ & 1.00 & -6.2 & 0.3 & -9.6 & 0.03 & 0.04 \\
\hline 10 & 1.20 & -2.9 & 0.1 & -5.4 & 0.12 & 0.09 \\
\hline $11^{* *}$ & 0.05 & 6.6 & 23.8 & -0.2 & 7.29 & 4.00 \\
\hline $12^{* *}$ & 0.05 & 6.9 & 23.7 & -1.4 & 6.10 & 3.23 \\
\hline
\end{tabular}

*August 26, 1987 to May 10, 1988.

**May 20, 1988 to August 26, 1988. 
in sediments on top of the cliff. At the foot of the cliff, water was mainly supplied from snow and ice that melted in situ. The temperature at a depth of $0.6 \mathrm{~m}$ shows a smooth yearly cycle. A local snow patch in mid-September minimized heat loss to the air, and an area at the base of the cliff remained relatively warm most of the autumn and early winter (Fig. 5). Thermistor 3 was cooled slowly to a minimum temperature of $-6.3^{\circ} \mathrm{C}$ in the middle of February.

The thermistors on the beach and upper part of the cliff showed large fluctuations at subzero temperatures during autumn. The maximum freezing rate was $0.78^{\circ} \mathrm{C} / \mathrm{h}$. In late October a

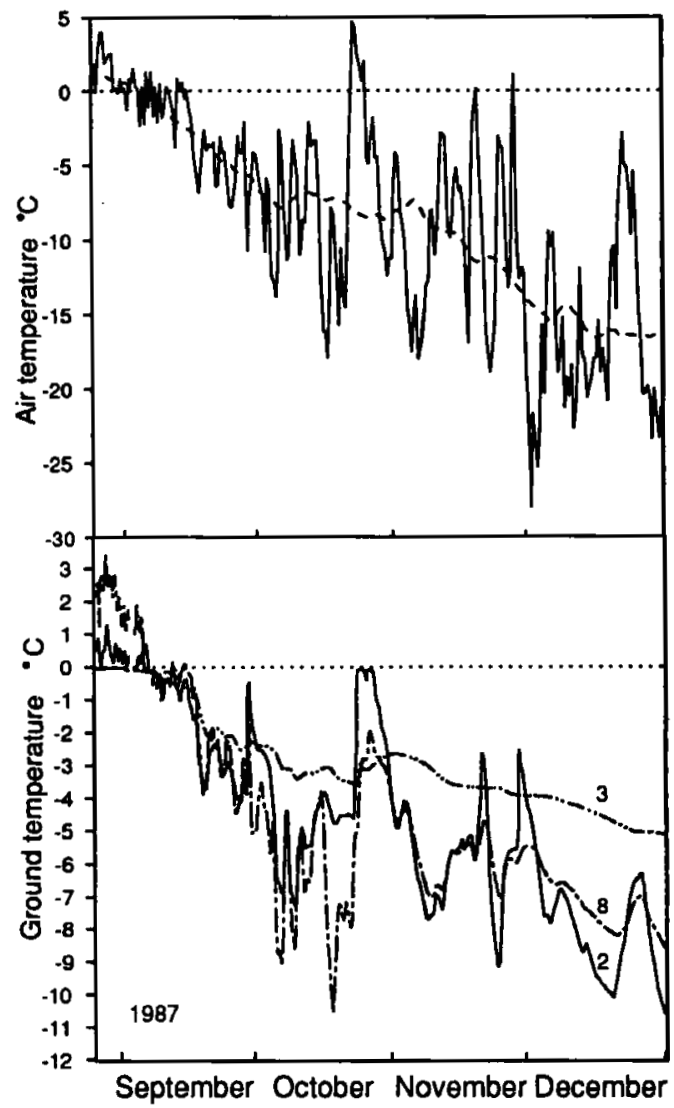

Fig. 5. The upper graph gives air temperatures from the meteorological record in Ny-Ålesund. Only observations at 07:00 and 19:00 are plotted. Maximum and minimum temperatures between these obscrvations are not included. The dashed lines indicate 30-day moving averages. The lower graph gives ground temperatures during autumn freeze. The numbers refer to thermistor numbers. period of three days of surface melt occurred (Fig. $5)$.

\section{Late winter}

At the cliff base (thermistor 3), the temperature rose from a minimum of $-6.3^{\circ} \mathrm{C}$ in mid-February to $-5.8^{\circ} \mathrm{C}$ in mid-April. In late winter thermistor 3 continued to record low temperatures (Fig. 6). Temperatures remained below $-5^{\circ} \mathrm{C}$ for more than four months. Thermistor 8 in the cliff showed temperatures slightly below those at the foot of the cliff. In March and April temperatures varied between $0.36^{\circ} \mathrm{C}$ and $0.46^{\circ} \mathrm{C}$, corresponding to gradients of $0.14^{\circ} \mathrm{C} / \mathrm{m}$ to $0.18^{\circ} \mathrm{C} / \mathrm{m}$. The other three thermistors on the beach also showed stable

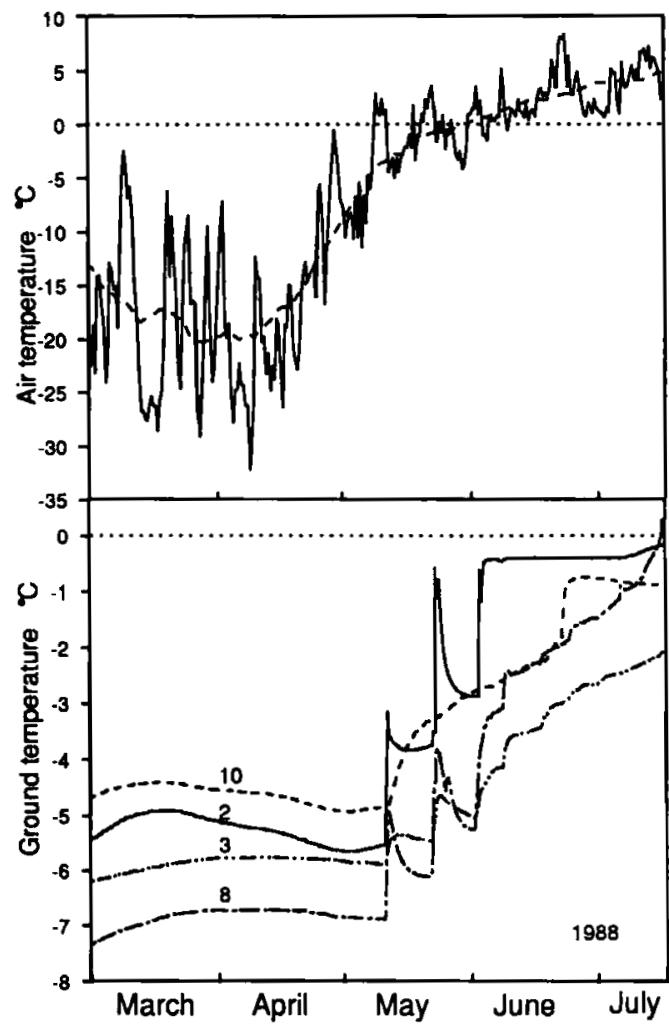

Fig. 6. The upper graph gives air temperatures from the meteorological record in Ny-Älesund. Only observations at 07:00 and 19:00 are plotted. Maximum and minimum temperatures between these observations are not included. The dashed lines indicate 30-day moving averages. The lower graph gives ground temperatures during spring thaw. The numbers refers to thermistor numbers. 
temperatures from March to April ranging from $-4.4^{\circ} \mathrm{C}$ to $-5.6^{\circ} \mathrm{C}$.

\section{Snow-melt period in spring}

Ground temperature records reveal distinct temperature anomalies during spring on portions of the rock wall not exposed to direct insolation. The ground temperatures at snow-covered sites in late winter were stable until the first snow melt in the beginning of May. As discussed later, it is presumed that release of latent heat from the refreezing of meltwater in the snow cover and sediments caused a steep rise in ground temperature. At the onset of thaw the rock wall was covered with several metres of snow. In the spring there were two periods of surface melt each followed by surface cooling of bedrock and sediments to subzero temperatures (Figs. 6 and 7).

Thermistor 8 , in the rock wall at $0.25 \mathrm{~m}$ depth, measured surface cooling during most of May, interrupted by short warming periods (Fig. 6). The maximum rise in temperature at thermistor 8 was $0.24^{\circ} \mathrm{C} / \mathrm{h}$, recorded during the second surface melting event. The maximum rise during the first event was not detected because of a break in the record on 10 and 11 May. The maximum rise in temperature in shore sediments at the second period of snow melt was $2.9^{\circ} \mathrm{C} / \mathrm{h}$ at thermistor 2 , observed 22 May (Fig. 6). The site was covered

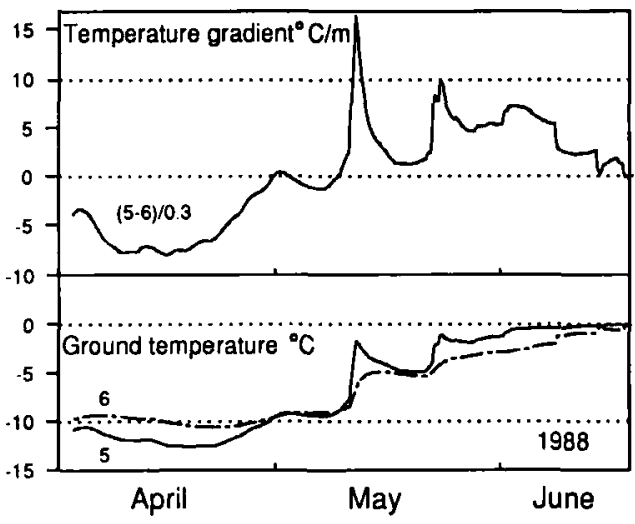

Fig. 7. Ground temperatures and gradients on top of the cliff during the spring thaw in 1988. Thermistor 5 (continuous line) at $0.05 \mathrm{~m}$ depth and thermistor 6 (dashed-dot line) at $0.35 \mathrm{~m}$ depth were placed $3.45 \mathrm{~m}$ apart. Horizont al heat flow is assumed negligible, and the differences are regarded as near surface temperature gradients during the period of snow-melt. with $2 \mathrm{~m}$ of snow. The steep rise is probably caused by percolation and subsequent refreezing of meltwater into the sediment. On 22 May the maximum air temperature was $4.2^{\circ} \mathrm{C}$. This was the ninth day of air temperatures above $0^{\circ} \mathrm{C}$. The total surface snow melt was $0.15-0.20 \mathrm{~m}$, measured on a snow stake on top of the cliff (Fig. 4).

\section{Near-surface measurements in the coastal cliff in} summer

In addition to the 10 sensors shown in Fig. 2, two sensors were placed at a nearby site in the coastal cliff at $0.05 \mathrm{~m}$ depth $2.0 \mathrm{~m}$ and $3.0 \mathrm{~m}$ above the foot of the cliff (Fig. 3, thermistors 11 and 12), and measured from 20 May-26 August 1988 (Table 1). There was no snow at the thermistor locations. The lower thermistor was placed in a nearby vertical rock wall, the upper in a wall of about $70^{\circ}$. The average temperatures were $6.6^{\circ} \mathrm{C}$ and $6.9^{\circ} \mathrm{C}$, which are $2.7^{\circ} \mathrm{C}$ to $3.0^{\circ} \mathrm{C}$ higher than the average air temperature during the same period. The sensor cables were protected by aluminum tape to minimize direct heating by radiation. The rock surface was frequently $8^{\circ} \mathrm{C}$ to $10^{\circ} \mathrm{C}$ warmer than the maximum air temperatures in periods of direct insolation. The maximum rock temperatures were $23.7^{\circ} \mathrm{C}$ and $23.8^{\circ} \mathrm{C}$.

These near surface temperatures $(0.05 \mathrm{~m}$ depth) on the north-facing coastal cliff exhibit the most drastic temperature fluctuations. Rapid temperature changes were recorded during nights when the weather suddenly changed from fog to direct insolation or vice versa. The fastest temperature rise was recorded 15 June 1988 from $04: 18$ to $05: 18$. The rates for thermistors 11 and 12 were $7.3^{\circ} \mathrm{C} / \mathrm{h}$ and $6.1^{\circ} \mathrm{C} / \mathrm{h}$, respectively. The meteorological record shows a change from fog to sun at this time. The maximum recorded cooling rates of $4.0^{\circ} \mathrm{C} / \mathrm{h}$ and $3.2^{\circ} \mathrm{C} / \mathrm{h}$ were measured July 24 between 10:34 and 11:34 and May 25 between 04:18 and 05:18.

\section{Discussion}

\section{Interpretation of near surface temperature} gradients and heat flow

Interpretations of the thermal regime in autumn, late winter, spring and late summer are depicted 
in Fig. 8A-D. The ice-foot and later sea ice protected the upper inter tidal zone and the backshore from waves during autumn and winter. Snow accumulated undisturbed, reaching a maximum depth of four to five metres in February. The accumulation and melting of snow on the beach had a strong local influence on near surface heat flow and moisture conditions during the entire year, from the first snow accumulation in September 1987 until the end of the snow melt in August the following year.

Autumn and early winter. - In early autumn most of the rock cliff cooled rapidly at the surface to temperatures considerably below $0^{\circ} \mathrm{C}$ (Fig. 8A). Average temperature gradients calculated from thermistors 5 and 6 , were about $9^{\circ} \mathrm{C} / \mathrm{m}$ in the upper $0.3 \mathrm{~m}$ of marine deposits on top of the cliff in November. A local snow patch at the foot of the cliff in September prevented strong surface cooling.

Late winter. - During late autumn and early winter, the snow cover stabilized ground temperatures and the near surface heat flow on the backshore and in the lower parts of the cliff (Fig. 8B). The vertical component of heat flow in the cliff can be calculated from the late winter differences in temperature between thermistor 3 at the foot of the cliff and thermistor 8 in the rock cliff. Assuming a thermal conductivity in the bedrock of $2.3 \mathrm{~W} / \mathrm{mK}$, the vertical heat-flux ranges from 0.3 to $0.4 \mathrm{~W} / \mathrm{m}^{2}$. Because of the low rates of heat flow and stable temperatures during two to three months, the measured temperatures in beach sediments probably do not deviate much from the temperature at the base of the snow (BTS).

The surface ground temperature under thick snow cover in late winter is mainly controlled by the temperature of the underlying permafrost (Haeberli 1973; Haeberli \& Patzelt 1982). BTSmeasurements might be used as a quick and reliable way to obtain estimates of the permafrost temperature (King et al. 1992). The temperature from February to May at thermistor 3 was less than $1^{\circ} \mathrm{C}$ colder than the MAGT at the top of the cliff. The higher late-winter temperatures in beach sediments close to the sea, compared to those at the foot of the cliff, indicate a lateral heat flow from the sea which causes a warmer permafrost close to the intertidal zone (Fig. 8B).

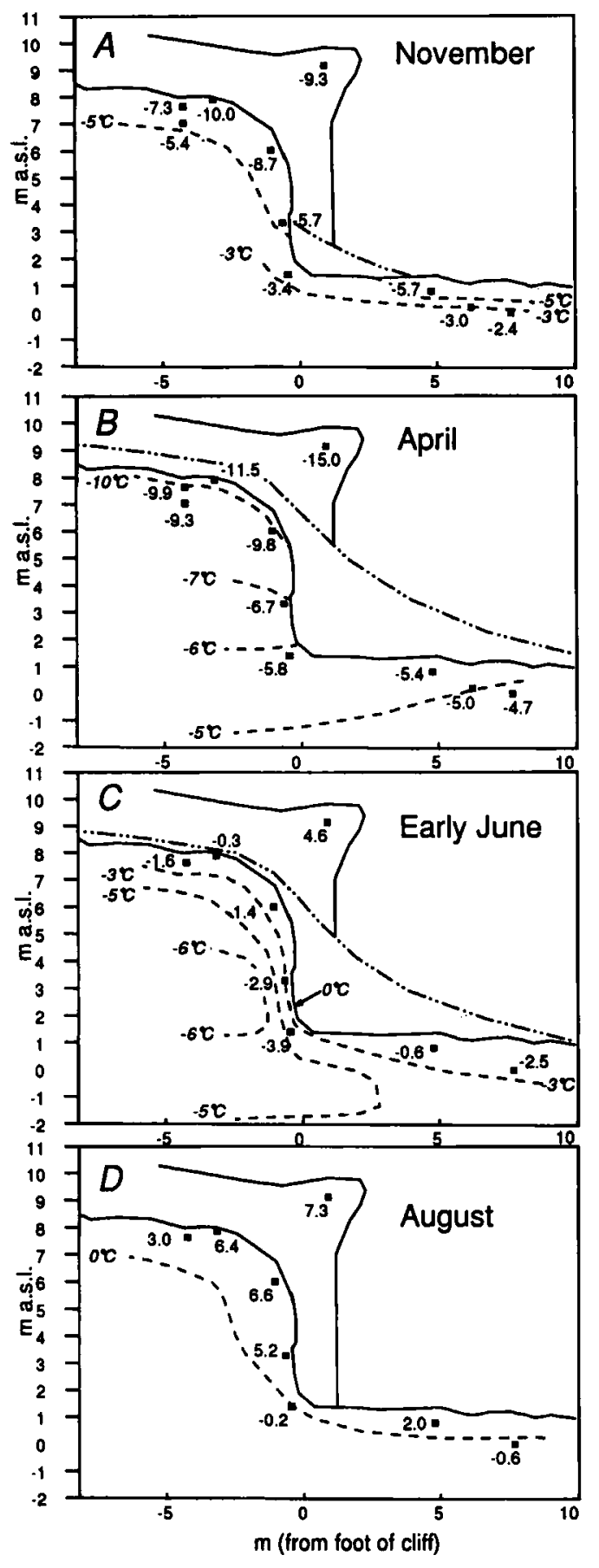

Fig. 8. Ground temperatures in November, April, early June (1-15) and August. Numbers at the thermistor locations are average values in the period. Dashed lines indicate isothermal lines. The arrow in early June points to a zone of steep surface temperature gradients during snow melt. 
No temperature measurements were made in the intertidal zone.

Snow-melt period in spring. - At the first snowmelt events in spring, we infer that the sudden release of latent heat from the refreezing of meltwater caused a large heat flux into the ground. In the cliff top sediments maximum temperature gradients occurred during the first period of surface melt, with peak values of about $15^{\circ} \mathrm{C} / \mathrm{m}$ calculated from thermistors 5 and 6 (Fig. 7). The temperature decreased with depth.

In the first week of June the snow pack probably became nearly isothermal at $0^{\circ} \mathrm{C}$, and thereby buffering strongly the temperature at the rock and sediment surface until the snow melted. At the top of the cliff the snow remained until late June; at the foot of the cliff until mid-August. During the snow-melt period, the temperature gradient at depth decreased (Fig. 7), and hence also the refreezing of meltwater at the surface. Near-surface temperature gradients increased abruptly as soon as the snow and ice cover vanished.

Near-surface temperatures in the rock wall in summer. - Instantaneous rates of temperature change at the surface were considerably higher than the observed value of $7.3^{\circ} \mathrm{C} / \mathrm{h}$ because of the depth of the measurement $(0.05 \mathrm{~m})$ and the long sampling interval ( 1 hour). Large temperature gradients occurred at sudden changes in insolation. More detailed interpretations are difficult on such limited temperature data.

Because of the dependence of the thermal regime on local factors such as sea-ice conditions, ice-foot morphology, moisture conditions and snow cover, care must be taken in generalizing. However, the main characteristics of the observed heat flow in late winter and the surface temperatures at the onset of thaw are probably typical for large areas of the coast of Svalbard. At sites where snow accumulates on the beach, temperatures approaching mean annual ground temperature of near coastal areas are probably reached every year at the foot of the cliff in spring before the onset of thaw, independent of the variations in air temperatures and snow cover during autumn. These strongly buffered thermal conditions are probably typical for the fjord areas in northern Spitsbergen and the eastern coast. On the western coast, where the measurements were made, sea-ice conditions are known to show great variability from season to season. Because of the cold winter in $1987 / 88$, there was extensive sea ice during the measuring period.

\section{The potential for cryogenic weathering}

The relation between thermal regime, moisture content and rock fracturing is not fully understood, and the following discussion is mostly conceptual. The discussion is restricted to rock fracturing related to the phase changes of $\mathrm{H}_{2} \mathrm{O}$ and is based on an interpretation of seasonal changes in ground temperature and heat flow. The importance of diurnal temperature variations and thermal stresses are difficult to evaluate based on the shallow temperature measurements recorded in summer. Nevertheless, these processes could be important for rock fracturing directly below the surface of the rock wall (Hall \& Hall 1991).

Lautridou (1988) suggests that bursting in noncracked rocks is caused by the pressure of the water in the core of the rock whose movement is blocked by the freezing front, with absorbed water possibly playing a small additional role. Assuming the water pressure arises from the $9 \%$ volumetric expansion when water freezes, great expansive pressure is only possible in a closed system in rocks close to saturation. Whether these conditions are often met in nature is questionable (Hall 1986). Since no measurements of moisture conditions exist, the potential of a volumetric expansion model cannot be evaluated.

Both laboratory research and theoretical models show that water migrates toward a single freezing front in rocks in a similar way to what is well known in soils (Fukuda 1983; Hallet 1983; Walder \& Hallet 1986). This water migration can generate heaving pressures in freezing soils that attain values of more than $18 \mathrm{MPa}$ (Radd \& Oertle 1973). The ice pressure in excess of water pressure depends on the temperature at which water freezes. Ice pressures necessary to expand microcracks in sound rock are on the order of $10 \mathrm{MPa}$ (Hallet 1983). In an open system such pressures are only possible at temperatures several degrees below zero. Water absorbed on the surface of minerals remains unfrozen at temperatures considerably below $0^{\circ} \mathrm{C}$. The low ice pressures associated with the freezing of water in cracks in an open system close to $0^{\circ} \mathrm{C}$ have little importance with regard to rock fracturing.

Segregation ice growth in cracks at subzero 
temperatures does not require cooling temperatures. Accelerated segregation ice growth can even occur during periods of temperature rise at the rock surface, assuming that water transport is the limiting factor. The hydraulic conductivity at subzero temperatures will increase with rising temperature. This seemingly paradoxical situation, that ice growth can be accelerated by surface heating, is discussed by Hallet et al. (1991, page 293).

The mobility of unfrozen water at subzero temperatures is critical to the model of segregation ice growth at subzero temperatures. In the experimental study a porous sandstone was used (Hallet et al. 1991). In the field situation described here the hydraulic conductivity along interconnected cracks is probably important in addition to the properties of the rocks. Costal cliffs along the coast of Svalbard are generally heavily fractured. During the snow-melt period these cracks are mostly ice-filled. Williams \& Smith (1989, page 199) suggest that ice masses in a frozen soil do not represent barriers that would greatly limit soil permeability. The analogy to ice-filled cracks is speculative but could be significant, especially in rocks of low permeability. If continuous air-filled passages exist along the cracks, migration of water vapor can occur.

Autumn and early winter. - The temperature measurements in the rock wall in autumn indicated a dry freezing with negligible latent heat effects. The rapid freezing of the rock wall probably limits segregation ice growth in periods of surface cooling in autumn. Due to an early snow cover the foot of the cliff remained relatively warm during autumn, but the sustained temperature gradients were low and there was probably limited available water.

Conditions considered favorable for segregation ice growth at subzero temperatures occur during melting periods in autumn, but only for a few days. Temperature gradients and moisture conditions during periods of surface melt are discussed in more detail below.

Snow-melt period in spring. - At the investigated coastal cliff the temperature gradients and moisture conditions in the period of snow-melt in spring could lead to segregation ice growth at sustained subzero temperatures according to the model by Hallet (1983) because (1) the release of heat from the refreezing of meltwater caused steep gradients with values on the order of $5^{\circ} \mathrm{C} / \mathrm{m}$ to $15^{\circ} \mathrm{C} / \mathrm{m}$ in the outer $0.25 \mathrm{~m},(2)$ the temperature of the bedrock just below the surface $\left(-4^{\circ} \mathrm{C}\right.$ to $\left.-6^{\circ} \mathrm{C}\right)$ is low enough to cause high ice pressures yet not so low as to hinder water migration significantly, (3) favorable conditions last for several days or weeks, allowing time for segregation ice growth even at low hydraulic conductivities, and (4) when the snow cover has reached $0^{\circ} \mathrm{C}$ percolating meltwater is available at the rock surface at pressures close to atmospheric pressure (Fig. 8C). These thermal and moisture conditions fit the experimental study using acoustic emissions ( $\mathrm{Hal}$ let et al. 1991), except for the calculated temperature gradients which are lower and the duration which is slightly longer. At the foot of the cliff, the snow-melt period with available water at the surface lasted more than two months.

\section{Conclusions}

The main characteristics of the thermal regime are depicted in Fig. 8. The ice-foot and sea ice made it possible for a thick snow pack to accumulate undisturbed on the beach. The distribution of snow and ice on the backshore influenced moisture supply and surface heat exchange during most of the year. A local snow patch at the foot of the cliff in mid-September minimized heat loss to the air, and this area remained relatively warm most of the autumn and early winter. In late winter a snow cover of 1-4 m stabilized ground temperatures and heat flow. The rock surface temperatures at the onset of thaw ranged from $-6^{\circ} \mathrm{C}$ at the foot to $-9^{\circ} \mathrm{C}$ in upper parts of the cliff (Fig. 8B). The first periods of snow melt in spring were characterized by a large heat flux into the ground due to the release of latent heat from refreezing of meltwater. At the foot of the cliff snow and ice remained until August.

The described thermal regime in spring and summer is probably typical for this type of coast in northern and eastern Svalbard, where sea ice is stable in winter and snow accumulates in front of the cliffs. On the western coast, where the measurements were made, sea-ice conditions are unstable.

Our understanding of rock fracturing mechanisms related to the thermal regime is incomplete. The interpretation and discussion above actually suggest that the spring and summer snowmelt periods are favorable for crack expansion 
and rock fracturing in the studied transect. This is based on the model of segregation ice growth at subzero temperatures (Hallet 1983; Walder \& Hallet 1986; Hallet et al. 1991). At the foot of the cliff favorable temperature gradients and moisture conditions lasted throughout most of the summer, but the temperature gradient decreased from the first snow melt events in the spring until the total disappearance of snow in August. Similar conditions also occurred during melting periods in autumn, but only for a few days. The hydraulic conductivity in heavily fractured rocks at subzero temperatures is critical in this model.

The importance of thermal stresses, diurnal temperature variations in the outer shell and the potential of volumetric expansion models are difficult to evaluate based on the field data. Studies of the thermal regime of Arctic coastal rock cliffs are continuing in Liefdefjorden, northern Spitsbergen, for comparison with the results from $\mathrm{Ny}$ Ålesund.

Acknowledgements. - Thanks are expressed to O. Liestøl for constructive advice, and to B. Lefauconnier who monitored snow melt during spring and early summer. The staff of Norsk Polarinstitutt and Kings Bay Kull Comp. A/S in Ny-Ålesund gave valuable help in installing and maintaining the equipment. The project received financial support from Norsk Polarinstitute in 1985, 1987 and 1988. J.-P. Lautridou gave constructive comments on an early draft of the manuscript. Additional comments by two anonymous referees improved the paper.

\section{References}

Ahlmann, H. W. 1919: Geomorphological studies in Norway. Geogra. Ann. 1, 3-252.

Forman, S., Mann, D. H. \& Miller, G. H. 1987: Late Wechselian and Holocene sea-level history of Brøggerhalvøya, Spitsbergen. Quat. Res. 27, 41-50.

Fukuda, M. 1983: The pore water pressure profile in porous rocks during freezing. In Permafrost, Fourth International Conference, Proceedings. National Academy Press, Washington, D.C. Pp. 322-327.

Haeberli, W. 1973: Die Basis-Temperatur der winterlichen Schneedecke als möglicher Indikator für die Verbreitung von Permafrost in den Alpen. Z. Gletscherkd. Glazialgeol. 9(12), 221-227.

Haeberli, W. \& Patzelt, G. 1982: Permafrostkartierung im Gebiet der Hochebenkar-Blockgletscher, Obergurl, Ötztaler Alpen. Z. Gletscherkd. Glazialgeol. 18(2), 127-150.

Hagen, J. O. \& Liestøl, O. 1990: Long-term glacier massbalance investigations in Svalbard 1950-88. Ann. Glaciol. 14, 102-106.

Hall, K. 1986: Rock moisture content in the field and the laboratory and its relationship to mechanical weathering studies. Earth Processes Landforms 11, 131-142.
Hall, K. \& Hall, A. 1991: Thermal gradients and rock weathering at low temperatures: some simulation data. Permafrost and Periglacial Processes 2, 103-112.

Hallet, B. 1983: The breakdown of rock due to freezing: a theoretical model. In Permafrost, Fourth International Conference, Proceedings. National Academy Press, Washington, D.C. Pp. $433-438$.

Hallett, B., Walder, J. S. \& Stubbs, C. W. 1991: Weathering by segregation ice growth in microcracks at sustained subzero temperatures: verification from an experimental study using acoustic emissions. Permafrost and Periglacial Processes $2,283-300$.

Høgbom, B. 1914: Über die geologische Bedeutung des Frostes. Pp. 294-206 in Sjøberg, H. (ed.): Bulletin of The Geological Institution of The University of Upsala 12.

Høgvard, K. \& Sollid, J. L. 1988a: Kystkart Svalbard B4 Bellsund 1:200,000 (printed map). Published by Geografisk institutt, Universitetet i Oslo and Norsk Polarinstitutt, Oslo.

Høgvard, K. \& Sollid, J. L. 1988b: Kystkart Svalbard B5 Sørkapp $1: 200,000$ (printed map). Published by Geografisk institutt, Universitetet i Oslo and Norsk Polarinstitutt, Oslo.

Høgvard, K. \& Sollid, J. L. 1989: Kystkart Svalbard C4 Edgeøya 1:200,000 (printed map). Published by Geografisk institutt, Universitetet $i$ Oslo and Norsk Polarinstitutt, Oslo.

Høgvard, K. \& Sollid, J. L. 1990: Kystkart Svalbard B3 Storfjorden Nord 1:200,000 (printed map). Published by Geografisk institutt, Universitetet i Oslo and Norsk Polarinstitutt, Oslo.

Høgvard, K. \& Sollid, J. L. 1991: Kystkart Svalbard C3 Olgastretet 1:200,000 (printed map). Published by Geografisk institutt, Universitetet i Oslo and Norsk Polarinstitutt, Oslo.

Høgvard, K. \& Sollid, J. L. 1992: Kystkart Svalbard C2 Hinlopenstretet 1:200,000 (printed map). Published by Geografisk institutt, Universitetet i Oslo and Norsk Polarinstitutt, Oslo.

King, L., Gorbunov, A. P. \& Evin, M. 1992: Prospecting and mapping of mountain permafrost and associated phenomena. Permafrost Periglacial Processes 3, 73-81.

Lautridou, J.-P. 1988: Recent advances in cryogenic weathering. Pp. 33-47 in Clark, M. J. (ed.): Advances in Periglacial Geomorphology. John Wiley \& Sons, New York.

Lautridou, J.-P. \& Ozouf, J. C. 1982: Experimental frost shattering: 15 Years of Research at the Centre de Géomorphologie du CNRS. Progress in Physical Geography 6, 215-232.

Letavernier, G. and Ozouf, J. C. 1987: La gélifraction des roches et des parois calcaires. Bulletin de l'Association Française pour l'Étude du Quarternaire 3, 139-145.

Liestøl, O. 1988: The glaciers in the Kongsfjorden area, Spitsbergen. Norsk Geografisk Tidsskrift 42, 231-238.

McGreevy, J. P. 1981: Some perspectives on frost shattering. Prog. Phys. Geogra. 5, 56-75.

McGreevy, J. P. \& Whalley, W. B. 1982: The geomorphic significance of rock temperature variations in cold environments: a discussion. Arc. Alp. Res. 14(1), 157-162.

Mellor, M. 1973: Mechanical properties of rock at low temperatures. In North American Contribution, Permafrost, Second International Conference. National Academy Press, Washington, D.C. Pp. 334-344.

Nansen, F. 1922: The strandflat and isostasy. Videnskapsselskapets Skrifter. I. Mat.-Naturv. Klasse. 1921. No. II. 313 pp.

Ødegård, R., Sollid, J. L. \& Trollvik, J. A. 1987: Kystkart Svalbard A3 Forlandsundet 1:200,000 (printed map). Published by Geografisk institutt, Universitetet $i$ Oslo and Norsk Polarinstitutt, Oslo. 
Ødegård, R., Sollid, J. L. \& Liestøl, O. 1992: Ground temperature measurements in mountain permafrost, Jotunheimen, Southern Norway. Permafrost Periglacial Processes 3, 231-234.

Orvin, A. K. 1944: Litt om kilder på Svalbard. Norsk Geog Tidssk. 10(1), $24 \mathrm{pp}$.

Radd, F. J. \& Oertle, D. H. 1973: Experimental pressure studies of frost heave mechanisms and the growth-fusion behavior of ice. In North American Contribution, Permafrost, Second International Conference. National Academy Press, Washington, D.C. Pp. 377-384.
Reusch, H. 1894: Strandflaten, et nyt trak i Norges geografi. Norges Geologiske Unders gelse 14, 1-14.

Walder, J. S. \& Hallet, B. 1986: The physical basis of frost weathering: toward a more fundamental and unified perspective. Arc. Alp. Res. 18, 27-32.

Williams, P. J. \& Smith, M. W. 1989: The frozen earth. Cambridge University Press, Cambridge. 306 pp.

Wiseman, Wm. J., Jr. \& Coleman, M. 1978: Field trip report, Norway and Spitsbergen. Louisiana State University, Baton Rouge, Louisiana. 